\title{
Kardiovaskulární mortalita u diabetu
}

\author{
Jan Škrha jr, Jan Škrha \\ III. interní klinika - klinika endokrinologie a metabolismu 1. LF UK a VFN v Praze
}

\begin{abstract}
Úvodem
Diabetologie se $v$ posledních letech více než kdy dřive zabývá vlivem léčby na celkovou kardiovaskulární morbiditu a mortalitu. Je nepochybné, že očekávaná délka života při diabetu je ovlivněna nejen samotnou hyperglykemií, ale i dalšími (nejen) metabolickými faktory. Se stárnoucí populací pribývá osob s kombinací závažných metabolických (diabetes mellitus) a kardiovaskulárních onemocnění (např. infarkt myokardu nebo iktus). Zatímco jsou dostupná poměrně přesná data o mortalitě u těchto jednotlivých diagnóz, není vůbec jasné, jak kombinací rizikových diagnóz morbidita dále narůstá. Výzkumy v této oblasti jsou komplikované, nebot je problematické zajistit dostatečně velkou kontrolní skupinu a detailně ji dlouhodobě sledovat.
\end{abstract}

\section{Analýza vztahu mezi mortalitou}

a kardiometabolickou multimorbiditou Registry Emerging Risk Factors Collaboration a UK Biobank

Autoři skupiny Emerging Risk Factors Collaboration publikovali v roce 2015 v JAMA analýzu vztahu mezi mortalitou a kardiometabolickou multimorbiditou, kterou definovali jako prítomnost alespoň 2 a více diagnóz z následujících - diabetes mellitus, iktus, infarkt myokardu [1]. Analyzována byla data 689300 účastníků z registru Emerging Risk Factors Collaboration (ERFC) z let 19602007 a následně byla srovnána s výsledky prospektivní kohortové studie 499808 účastníků studie UK Biobank $z$ let 2006-2010.

Do registru ERFC byly zařazeny prospektivní studie, které obsahovaly informace o prípadném diabetu, iktu a infarktu myokardu, neselektovaly pacienty s predchozím chronickým onemocněním, zároveň zaznamenávaly prríčiny úmrtí a trvaly alespoň 1 rok. Během sledování bylo v registru ERFC popsáno asi 129000 úmrtí.

$\checkmark$ registru UK Biobank splnilo kritéria pro vyhodnocení (tedy mělo vstupní anamnézu diabetu, iktu či infarktu myokardu) 499808 osob z 22 center Spojeného království a během sledování $v$ tomto registru došlo k asi 8000 úmrtím.

Účastníci z obou registrů byli rozděleni do 8 kategorii: (1) diabetes, (2) iktus, (3) infarkt myokardu, (4) diabetes a infarkt myokardu, (5) diabetes a iktus, (6) iktus a infarkt myokardu, (7) diabetes, iktus a infarkt myokardu, (8) referenční skupina osob bez uvedených diagnóz, přičemž v každé skupině bylo stanoveno riziko úmrtí.
Kompletní analýza zahrnula více než 135000 úmrtí mezi sledovanými 1,2 milionů osob.

Bylo prokázáno, že prítomnost jedné sledované diagnózy zvýšila riziko úmrtí (HR - hazard ratio) 2násobně, přitomnost 2 sledovaných diagnóz 4násobně a prítomnost všech 3 sledovaných diagnóz (diabetu, iktu, infarktu myokardu) až 8násobně. Ukazuje se, že kardiometabolická multimorbidita snižuje odhadovanou délku života podobně významně jako např. celoživotní nikotinizmus či infekce virem HIV. Kardiometabolická multimorbidita $v 60$ letech života vedla $\mathrm{k}$ průměrnému zkrácení života o 15 let, kombinace všech 3 sledovaných diagnóz ve 40 letech zkrátila život v průměru o 23 let.

Zatímco mortalita v prípadě samotného diabetu, samotného iktu nebo samotného infarktu myokardu se významně neliší, současná kombinace těchto diagnóz má násobný vliv na celkovou mortalitu, a dramaticky tak zkracuje odhadovanou délku života (graf). Je tedy pravděpodobné, že vztah mezi diabetem a kardiovaskulárními onemocněními a mortalitou je komplexní a je třeba mu věnovat náležitou pozornost. Význam prevence kardiovaskulárního onemocnění u diabetiků, resp. snaha o odvrácení diabetu u kardiaků tak ve světle těchto výsledků nabývá na důležitosti.
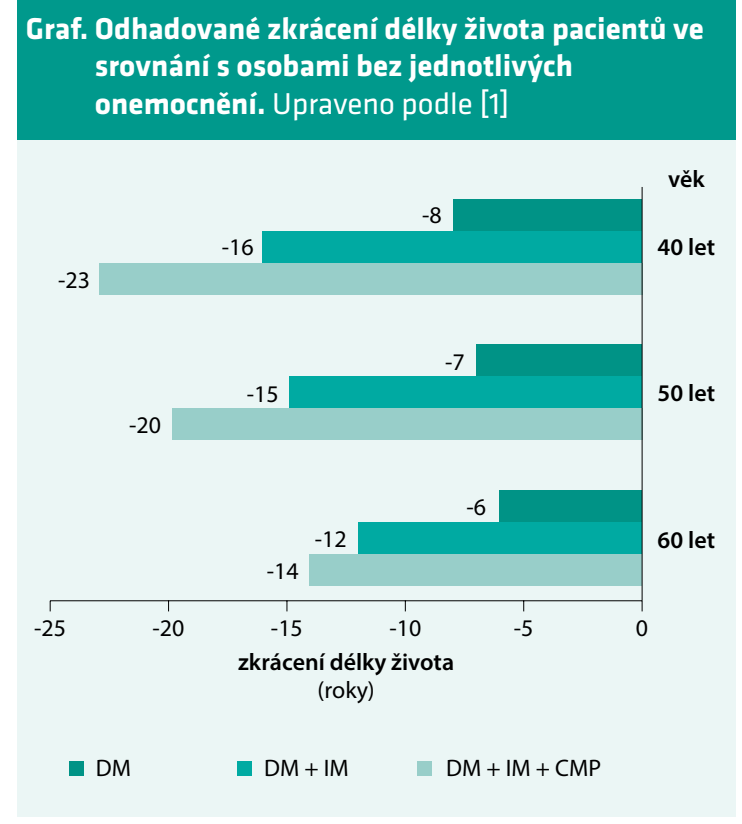


\section{Multifaktoriální intervence - výsledky národních intervenčních studií}

Velké národní intervenční studie (DCCT - Diabetes Control and Complications Trial, UKPDS - United Kigndom Prospective Diabetes Study, CARDS - Collaborative Atorvastatin Diabetes Study a další) v nedávné minulosti prokázaly zásadní význam léčby hyperglykemie, dyslipidemie i arteriální hypertenze u osob s diabetem a efekty takové multifaktoriální intervence $v$ posledních 20 letech již Ize pozorovat.

\section{Trend celkové a kardiovaskulární mortality u diabetiků ve Švédsku}

Dlouhodobé trendy celkové a kardiovaskulární mortality veŠvédsku u osob s diabetem ukazuje recentní publikace Rawshaniho et al v New England Journal of Medicine [2]. Data vycházejí ze švédského národního diabetického registru (NDR - National Diabetes Register). Do prezentované analýzy byly zařazeny osoby, které vstoupily do registru v období mezi lety 1998 a 2012 a byly sledovány do konce roku 2014. Celkem byla vyhodnocena data 36869 pacientů s diabetem 1. typu, 457473 pacientů s diabetem 2. typu a srovnatelné množství kontrolních osob bez diabetu. Během sledování (medián 15 let) došlo k mírnému vzestupu glykovaného hemoglobinu u diabetiků 1. typu (ze 66,2 na $68,4 \mathrm{mmol} / \mathrm{mol}$ ) a mírnému poklesu u diabetiků 2. typu (z 60,2 na $56,7 \mathrm{mmol} / \mathrm{mol})$, zároveň v obou skupinách významně poklesly koncentrace LDL-cholesterolu, hodnoty krevního tlaku či prevalence makroalbuminurie. Absolutní snížení celkové mortality v uvedeném období bylo pozorováno jak u diabetu 1. typu (-31,4 úmrtí na 10000 osobo-roků, resp. -13,9 úmrtí na 10000 osobo-roků u srovnatelných kontrol), tak u diabetu 2. typu (-69,6 úmrtí na 100000 osobo-roků, resp. -134,7 úmrtí na 10000 osobo-roků u srovnatelných kontrol). Mortalita tak u osob s diabetem 1. typu poklesla o $29 \%$ oproti $23 \%$ poklesu u srovnatelných kontrol, naproti tomu u osob s diabetem 2. typu poklesla mortalita o $21 \%$, zatímco u srovnatelných kontrol dokonce o $31 \%$. Rovněž ubylo úmrtí z kardiovaskulárních príčin - o $42 \%$ u diabetu 1. typu a $38 \%$ u srovnatelných kontrol, resp. o $46 \%$ u diabetu 2. typu a $52 \%$ u srovnatelných kontrol. Zároveň bylo pozorováno snižení počtu hospitalizací z kardiovaskulárních príčin o $36 \%$ u diabetu 1. typu a $44 \%$ u diabetu 2. typu. Nebyl pozorován rozdíl v počtu hospitalizací pro srdeční selhání u diabetu 1. typu a ve všeobecné populaci, zatímco osoby s diabetem 2 . typu byly hospitalizovány o 29 \% méně. Snížení fatálních příhod se tedy př́liš nelišilo mezi diabetiky 1. typu a kontrolami, $v$ prípadě osob s diabetem 2. typu bylo toto snížení menší než v kontrolní populaci. Naproti tomu nefatální príhody mezi osobami s diabetem 1.i 2. typu poklesly výrazně více než v kontrolních skupinách. Přesto však zůstává incidence těchto príhod v diabetické populaci vyšší než v běžné nediabetické populaci.

Autoři se zamýšlejí nad možnými faktory zjištěného zlepšeného přeživání. Uvádějí vliv komplexnější lékařské péče, lepší edukace pacientů s diabetem, zlepšení revaskularizačních technik i př́nos častější a jednodušší monitorace glykemie. Za nejvýznamnější faktor vedoucí $\mathrm{k}$ nižší kardiovaskulární mortalitě však považují účinnější léčbu rizikových faktorů (arteriální hypertenze, dyslipidemie, hyperglykemie).

\section{Závěry}

Význam kardiovaskulárních komplikací u diabetu je nesporný a nejen výše uvedená práce založená na registru Emerging Risk Factors Collaboration ukazuje násobné zvýšení mortality při kombinaci několika závažných kardiovaskulárních diagnóz. Na druhou stranu ale víme, že Ize kardiovaskulární riziko ovlivnit - nejen režimovými opatřeními, omezením nikotinizmu, ale také farmakologickou intervencí některých rizikových faktorů. Je dobře, že i diabetologie se od úzce glukocentrického př́stupu pomalu posouvá ke komplexnímu pohledu na pacienta.

\section{Komentář k výskytu kardiovaskulárnich komplikaci u diabetilků 2. typu v České republice}

V letech 2002-2010 probíhalo v České republice epidemiologické šetření o diabetu, které inicioval výbor České diabetologické společnosti. Výsledky za rok 2002 a 2006 byly zpracovány a publikovány $[3,4]$. Na počátku bylo osloveno 76 diabetologických ordinací, v nichž byli náhodně vybráni diabetici 1. a 2. typu podle zvoleného data narození (metodika je uvedena v obou publikacích). Celkově byla zpracována data při vstupní analýze za rok 2002 u 3206 diabetiků 2. typu.

Ischemická choroba srdeční (ICHS) se vyskytla u 41,6\% diabetiků 2. typu $s$ průměrnou délkou trvání diabetu $9 \pm 7$ let, z nichž u 3,8 \% byla popsána prodělaná akutní př́hoda a u 37,8 \% byla prítomna chronická ischemická choroba srdeční. Prodělaná cévní mozková príhoda (CMP) byla evidována u 11,4\% diabetiků. Relativní výskyt komplikací byl významně ovlivněn především trváním diabetu (při trvání $\leq 10$ let byl výskyt ICHS u 32 \%, kdežto při trvání > 10 let byl výskyt u $54 \%$ diabetiků 2. typu). Podobně tomu bylo u cévních mozkových príhod (8 \%

\begin{tabular}{|l|c|c|}
\hline $\begin{array}{l}\text { Tab. Výskyt komplikaci v procentech z celkového } \\
\text { počtu vyšetřených dliabetiků 2. typu. } \\
\text { Upraveno dle [4] }\end{array}$ \\
\hline \multicolumn{2}{|c|}{2002} & 2006 \\
\hline retinopatie (celkem) & 17,0 & 22,0 \\
\hline proliferativní & 2,0 & 2,7 \\
\hline ischemická choroba srdeční & 41,0 & 49,2 \\
\hline akutní & 3,6 & 2,2 \\
\hline chronická & 39,0 & 47,0 \\
\hline ischemická choroba dolních končetin & 20,6 & 25,0 \\
\hline diabetická noha & 3,4 & 5,8 \\
\hline cévní mozková př́hoda & 13,0 & 15,5 \\
\hline periferní neuropatie & 31,6 & 36,8 \\
\hline
\end{tabular}


vs $16 \%)$. Další faktory jako kompenzace diabetu vyjádřená $\mathrm{HbA}_{1 c^{\prime}}$ krevní tlak či koncentrace cholesterolu v séru nevedly k významnému rozdílu ve výskytu těchto komplikací. Kouření vedlo k poměrně malému navýšení výskytu ICHS, která byla u kuřáků v 38,9\% , zatímco u nekuřáků v 32,1\%.

Po 4 letech (2006) bylo zopakováno šetření, avšak data byla získána jen od 1261 diabetiků 2. typu evidovaných v 36 ordinacích. V nich došlo během 4 let $k$ úmrtí 242 diabetiků, z nichž 26 \% zemřelo na ICHS, $13 \%$ na CMP, ale vedle dalších diagnóz nebyla příčina úmrtí objasněna ve 30 \% případů. Šetření probíhalo u diabetiků, kteří byli zařazeni již v roce 2002, a tím i jejich diabetes trval o 4 roky déle. Během uvedených 4 let došlo k zintenzivnění léčby diabetu a zvýšila se preskripce antihypertenziv a statinů, což se promítlo do lepší kompenzace diabetu, snížení krevního tlaku, cholesterolu i triacylglycerolů. Zdvojnásobil se relativní počet diabetiků dosahujících cílových hodnot uvedených parametrů.

U sledovaného souboru 1261 diabetiků došlo k nárůstu výskytu ICHS z 41 \% (2002) na 49,2 \% (2006), na němž se podílela chronická forma ICHS $39 \%$ vs $47 \%$. Výskyt CMP se zvýšil z 13 \% (2002) na 15,5 \% (2006), tab.

$V$ dalších letech došlo $k$ úbytku jak zúčastněných center, tak pacientů, takže v roce 2010 mohla být provedena analýza cévních komplikací jen u 395 diabetiků 2. typu (nepublikováno). ICHS byla evidována u $50 \%$ pacientů, CMP u $13 \%$ těchto pacientů.

\section{Závěry}

Údaje o kardiovaskulárních komplikacích u diabetiků jsou v ČR jen orientační, nebot' dosud neexistuje jednotný registr. Podobná prospektivní epidemiologická studie nebyla provedena. Data z naší epidemiologické studie nelze srovnávat s oběma uvedenými pracemi, které jsou zaměřeny na mortalitu z kardiovaskulárních príčin. Navíc nejsou u nás k dispozici recentní data z posledních let. Nicméně výše uvedené nálezy svědčí o vysokém výskytu kardiovaskulárních komplikací u diabetiků 2. typu, který narůstá s délkou trvání diabetu. Při cukrovce s trváním delším než 10 let Ize očekávat výskyt těchto cévních komplikací téměř u poloviny pa- cientů, což je obrovský počet. Vedle kardiovaskulární morbidity však jsou tyto komplikace hlavní př́činou úmrtí diabetiků 2. typu. Ovlivnění jejich výskytu a rozvoje je možné a snížení mortality je realizovatelné, jak uvádí výše citovaná švédská studie [2].

\section{Závěrem}

Současné trendy v terapii diabetu poukazují na prognostickou závažnost kardiovaskulárních komplikací, a tím na potřebu zaměřovat výběr léků se zřetelem $k$ jejich vlivu na kardiovaskulární systém.

Výsledky studií z poslední doby, zejména EMPA-REG Outcome a LEADER, přinesly do diabetologie nový pohled a možnosti, jak ovlivnit dosavadní trendy vývoje vaskulárních komplikací diabetu. Vedle invazivní kardiologie tak vstupuje do hry i cíleně zaměřená farmakoterapie, která by měla být u všech diabetiků 2. typu s přítomným kardiovaskulárním onemocněním preferována před antidiabetiky bez prokázaného kardiovaskulárního benefitu. Účinné ošetření rizikových faktorů současně s příznivým účinkem na další vývoj ischemické choroby srdeční může podstatně zlepšit jak její průběh, tak i kvalitu života diabetika.

\section{Literatura}

1. Di Angelantonio E et al. Association of Cardiometabolic Multimorbidity With Mortality - The Emerging Risk Factors Collaboration. JAMA 2015; 314(1): 52-60.

2. Rawshani A et al. Mortality and Cardiovascular Disease in Type 1 and Type 2 Diabetes. NEJM 2017; 376(15): 1407-1418.

3. Škrha J. Diabetes mellitus 2002 v České republice - epidemiologická studie. Diabetologie, metabolismus, endokrinologie, výživa 2005; 8(1): 5-12.

4. Škrha J. Epidemiologická studie o diabetu mellitu v České republice. Porovnání výsledků z roku 2002 a 2006. Diabetologie, metabolismus, endokrinologie, výživa 2010; 13(1): 55-62.

\section{MUDr. Jan Škrha jr $\square$ jan.skrha@seznam.cz}

III. interní klinika - klinika endokrinologie a metabolismu 1. LF UK a VFN v Praze

www. int3.If1.cuni.cz

Doručeno do redakce 21. 6. 2017 